\begin{tabular}{lll}
\hline VOLUME (01) & Number (02) & Page (74-81)
\end{tabular}

\title{
ESP STUDENTS' PREFERENCES IN LEARNING ENGLISH: FACE TO FACE CORRECTIVE FEEDBACK VS ONLINE CORRECTIVE FEEDBACK
}

\author{
Nurizzi Rifqi Ferdian1, Nunu Nugraha Purnawan'2 \\ ${ }_{1,2}^{2}$ State Polytechnic of Subang \\ rifqi.ferdian@gmal.com
}

\begin{abstract}
The main goal of teaching and learning foreign language is to achieve students' language competenceby using effective ways. To fulfill the goal, corrective feedback has been implemented widely in order to assist students' competence and strengthen students' motivation. The current study aims to explore the students' preferences on face to face corrective feedback vs online corrective feedback in ESP class. It is an attempt to investigate if they prefer to be corrected directly face to face by teachers or they like to be provided online corrective feedback by the teachers. To do so, it was conducted involving totally 50students who were taking ESP course at State Polytechnic of Subang. They received a validated questionnaire of perceptionsonface to face corrective feedback vs online corrective feedback. Furthermore, a focus group discussion was used in order to find out their beliefs toward their corrective feedback preferences. Additionally, the results were thematically categorized andmanually analyzed. The results from the questionnaire analysis revealed thatthe students preferred their teachers to use face to face corrective feedback, with overall mean $(\overline{\mathrm{x}}=$ $3,95)$ in learning effectiveness, $(\bar{x}=4,12)$ in learning accuracies, and $(\bar{x}=4,02)$ in learning experiences. The focus group discussion revealed the students' beliefs in their corrective feedback preferences, they believed that the teachers should be able to guide their learning, use communicative ways, and encourage them by using their learning preferences. The study suggested that taking these preferences into consideration could help students to increase their confidence in learning English.
\end{abstract}

Keywords: Corrective Feedback, Face to faceCorrective Feedback, OnlineCorrective Feedback, English Learning

\section{Introduction}

The new paradigm has shifted both in language teaching and learning methods where the teachers are demanded to encourage their students in learning English. (Sipayung, 2019) stated English is rapidly gaining status as a global language. This is true because the language is not only used in English-speaking countries but also in other countries where businesses flourish through negotiations delivered in English. With regard to the importance of teaching method, corrective feedback comes as one of the teaching approaches which focus on correctness and exactness the students' mistakes and errors. Ellis (2009) stated that corrective feedback or error correction or grammar correction refers to teacher's response to students' utterances containing linguistic error. Corder (1974) added that students' errors are important for teachers as they indicate theamount of information that the students have acquired, and teachers can then modify their instruction according to theirstudents' needs. Therefore, the studies on corrective feedback have processed researchers' interest since error analysis became favored area for language teaching and learning.
The use of corrective feedbackis implemented by the teachers to prevent and correct learners' errors from getting fossilized.Ellis (2010) believed that learners' engagement with corrective feedback as how learners respond to that feedback. In addition, learner engagement with corrective feedback could assist the students to process, use, react and attract increasing scholarly attention in the field of language learning (Zhang, 2017; Zhang \& Hyland, 2018; Zheng \& Yu, 2018).Thus, concerning on the importance of language learning accuracy, the corrective feedback can be a step to foster the students on the use of accuracy both in writing and speaking.

The growing interest on the usage of technology in the field of foreign language teaching also affects to the corrective feedback. In other words, teachers' corrective feedback can be implemented both online corrective feedback and face to face corrective feedback. As mentioned by Richardson, "The technology is the means, not the content of the presentation. It should not overwhelm the lesson, but enhance it. If a nontechnology-based means of presentation would be more effective, then by all means use it. The 
simplest, most intriguing tool to impart instruction is the best tool. Paper and pencil can sometimes be more effective than computer equipment - and paper does not crash!” (2004, p. 14). Therefore, teachers must be able to integrate technology as effortless as possible by providing the most beneficial learning environment of written corrective feedback for their students, whether they learn better using a digital learning environment or face to face.

The studies of corrective feedback essentially have shown the possible helpfulness. Corrective feedback does lead to writing improvements (Hyland and Hyland, 2006) and the systematic analysis of errors can help researchers and teachers to understand better the process of language acquisition (Hendrickson, 1978). Moreover, the use of feedback for example as a medium for informing the students about their performance can help to reach the learning goals as well as for motivating and reinforcing their learning behavior (Nelson \& Schunn, 2009) and providing students with feedback in its various forms such as teacher feedback, peer and collaborative feedback, the provision of oral feedback in writing conferences, and computermediated feedback have been recommended and practiced in the classroom so far(Bitchener, Young \& Cameron, 2005; Montgomery \& Baker, 2007; Arslan, 2014; Ferris, 2014; Wang, 2014 Mahfoodh, 2016; Chong, 2016). Thus, the corrective feedback has shown that it can lead to better learning products.

Accordingly, this study examines the students' preferences because a research on students' preferences has reported that students expect teachers to comment on their errors and are frustrated if this does not happen (Hedgcock \& Lefkowitz, 1994; Ferris, 1995; Lee, 2004). Additionally, it is important in the learning and teaching process to consider learners' preferences in order to encourage English learning. Thus, for this purpose, this study aims at shedding some lights on the students' preferences in learning English, specifically to answer the following questions: what are the ESP students' preferences when teachers give corrective feedback, whether face to face or online? And what are the ESP students' beliefs towards their corrective feedback preferences?

Using and providing students with feedback for their learning is considered essential since it can be used to promote students' learning. In other words, one of the duties of language teachers is to provide feedback for their students in order to see whether they understand or whether the pedagogical practices meet students' expectations of instruction. This kind of feedback is known as corrective feedback or error correction or grammar correction. It is a crucial means adopted by teachers to treat learners' errors in second language (L2) classroom (Chen, Lin, \& Jiang, 2016). Moreover, Chaudron (1998) mentioned that corrective feedback is any kinds of teacher behavior that follow an error and try to inform the learners of the fact of error. Importantly, Chu (2011) highlighted that corrective feedback does not only emphasize the form of language, but it draws students' attention to linguistic forms as they arise incidentally during lessons whose overriding focus is on meaning or communication. Thus, the focus of corrective feedback is as the treatment of errors and provides guidance for the teachers. As a result, is then used by teachers to give feedback in English classrooms regarding the student's skills, types of mistakes and the situation.

As one of the language instructions, the use of corrective feedback nowadays is also adopted by many language instructors in which there has been a growing interest on the usage of technology in the field of foreign language teaching. Consequently, many language teachers have adopted new technologies and explored new paths to reach the goal of quality educational opportunities for the students. Even distance or virtual education has become an increasingly common alternative ways in language teaching. Some researchers found that using electronic tools is one of effective ways for students; learning. Hsieh, Wu and Marek (2017), Kaya (2015) and Sangeetha (2016) have used electronic to give feedback and they believed that most electronic tools have engaging features. Some studies also shown that students learn better when utilizing electronic when teacher give corrective feedback (Al-Kathiri, 2015; Al-Okaily, 2013; Al-Shehri, 2011). However, some researchers neglected that using virtual learning is not always good. Kirovska-Simjanoska (2016) stated that although digital education may provide an excellent opportunity to access education, but this method is not ideal for everyone. Additionally, it is no significant differences in effectiveness between distance education and face-to-face education and distance education can successfully replace faceto face instruction when it is the only option available. Though, academic research generally suggests that digital learning outcomes are similar to traditional classroom settings (Beare, 1989; McCleary \& Egan, 1989; Sonner, 1999). As a result,it can be concluded that, in the case of corrective feedback, the use of this method can be implemented both using face to face and online 
since there has no difference between distance and face-to-face learning overall.

Regardless of the ways of giving corrective feedback, English teachers should be able to provide the right corrective feedback for their students because it is believed that by using the student's preferred ways in learning, it can assist them to improve their abilities, skills, as well as motivate them to take charge of their own learning.

\section{Methodology}

This study was designed to collect the data fromstudents' preferences and beliefs when teachers give corrective feedback, whether face to face or online. Therefore, in accordance with it, theresearchers used the mixed methods approach since it aimed to clearly identify bothquantitative by using questionnaires and qualitative data by using Focus Group Discussions

(FGD).

\section{Participants and Setting}

To achieve the objectives of the study, 50 students who were taking English for Specific Purposes participated in this study. The students were those who took ESP course at that semester from two classes in Informatics Management department at State Polytechnic of Subang.Moreover, to have a rich dataset, 10 students who were willing to participate in Focus Group Discussion (FGD) were also questioned about their beliefs and thought on their preferences online corrective feedback and face to face corrective feedback.

\section{Procedure}

Before the students were requested to fill the questionnaires and answer the questions in FGD, the English teachers had implemented corrective feedback. The face to face corrective feedback was conducted by assigning the students to do some exercises in a piece of paper and the teachers then correct their errors in the class. While for the online corrective feedback, the teachers assigned the students to do some exercises in Edmodo. After the students finished the assignments in Edmodo, the teachers then correct their errors by giving some comments and at that moment, the students could automatically see their teachers' feedback.Finally, at the of end of the meeting, the students were then asked to fill the closed-ended questionnaire and join the FGD.

\section{Research Instrument}

Since this research aimed to analyze students' preferences and beliefs, a questionnaire was designed by the researchers. It had five points Likert-scale, ranging from the values 1 (strongly disagree) to 5 (strongly agree), and consisted of 15 items related to three different domains of face to face and online as shown in the table 1. The questionnaire was adopted and adapted from some scholars (Hamouda, 2011; Kirovska-Simjanoska, 2016; Han, 2019) and then developed by the researchers to meet the purposes of this study. The statements were acceptable to be used to answer the main research question of the study since the experts provided some statements on the use of corrective feedback in language learning. As stated by Dörnyei (2003, p. 31), the initial stage of questionnaire design should focus on clarifying the research problem and identifying what critical concepts need to beby the questionnaire. First domain perceived learning effectiveness in using face to face corrective feedback and online corrective feedback, second domain was learning accuracy in using face to face corrective feedback and online corrective feedback, and the third domain is learning experiences in using face to face corrective feedback and online corrective feedback.

The questionnaire was distributedwith a fivepoint Likert scale and was written in Bahasa Indonesia to ensure better understanding of the items, since theparticipants were native Indonesia speakers.Before implementing the questionnaire, since this instrument has not been used before, it was piloted with 32 students from different class. The results of the analysis of Pearson ProductMoment Correlation indicated that items in the questionnaire were valid because the average score of significant value was 0.021 and it was not higher than $0.05(0.017<0.05)$. At the 0.05 level, the items of questionnaire are valid when the significant value is $<0.05$ (Priyatno, 2014, p. 55). Moreover, to get better understanding of the students' beliefs of their learning preferences in face to face corrective feedback and online corrective feedback, FGD was conducted with the volunteers obtained from the participants who were willing to be volunteers in the group discussion. The use of focus group interviews was applied to give information about their beliefs on the topic and give great insight into why certain opinions were held, as well as produce insights for developing strategies for outreach.

\section{Data Analysis}

The quantitative data collected from the questionnaires were keyed into Statistical Package for Social Science (SPSS) version 23.0 to generate descriptive statistics and reveal the average and standard deviation value from the questionnaires results. The data obtained from the FGD were analyzed by content analysis to gain students' indepth understanding and orientation of the students' beliefs of face to face corrective feedback and online corrective feedback. The data 
were analyzed using content analysis. It is a research technique to identify thecontext of use (Krippendorff, 2004, p. 18). By studying the contexts of use, related theories can be analyzed. The steps were: breaking thedata into manageable pieces,interpreting the data pieces, and labelingthe emerging ideas with proper names which stand and represent the ideas contained in the data.

\section{Results and Discussion}

To answer the research questions, the quantitative results were presented in three domains of students' preferences in face to face corrective feedback (CF) and online corrective feedback (CF); learning effectiveness, learning accuracy, and learning experiences. While the qualitative results were coded by using content analysis.

What are the ESP students' preferences when teachers give CF; face to face CF or online CF?

All of the participants were asked by using a questionnaire related to their preferences in learning using toward corrective feedback. As a result,the quantitative results were presented in threedomains of students' preferences on the corrective feedback; learning effectiveness, learning accuracies, and learning accuracies. Details in actual words are shown below.

\section{Learning Effectiveness}

The participants were asked to measure their learning effectiveness when the teachers used face to face $\mathrm{CF}$ or online $\mathrm{CF}$. The overall mean value of theparticipants was $=3,95$. It can be concluded that the students adored when their teachers used face to face $\mathrm{CF}$ and online CF frequently. They believed that the teachers should often use face to face $\mathrm{CF}$ than online $\mathrm{CF}$ as shown in the table 2.

The statements from participants indicated that most of them preferred their teachers to use face to face than online CF frequently although both of them had strengths. They could get more understanding in face to face $\mathrm{CF}$ since they were able to ask their teachers directly without waiting. Additionally, the students seemed to feel more comfortable when their teachers use face to face CF since the explanation in face to face is understandable and they admitted the comments in face to face were more helpful and effective than in online as shown in the quantitative data $(\overline{\mathrm{x}}$ $=3,95)$. What the students believed was reasonable since the CF can assist the students' learning effectiveness. As mentioned by Lee (2013) and(Rahimi \& Zhang, 2015), the effectiveness of instant correction conducted by the teaches toward students' mistakes was able to improve their learning skills.Moreover, the learning effectiveness of CF was agreed by Marzban and Sarjami(2014) who showed that CF in universitylearners was effective. Thus, it should be pointed out that face to face $\mathrm{CF}$ seemed to be desired by students to create effective learning.

\section{Learning Accuracies}

The participants were questioned to assess their learning accuracies when the teachers used face to face $\mathrm{CF}$ or online $\mathrm{CF}$. The overall mean value of the participants was $=4,12$. It can be concluded that the students preferred when their teachers used face to face $\mathrm{CF}$ than online $\mathrm{CF}$ frequently. They believed that the teachers should regularly use face to face $\mathrm{CF}$ than online $\mathrm{CF}$ as shown in the table 3.

The students' perceptions showed that face to face is more communicative than online $\mathrm{CF}$ because it allowed the students to interact directly with their teachers where they could ask, comment, and even argue with their teachers while they could not do it online due to some problems. What the students stated was rational as Chu (2011) highlighted that corrective feedback does not only emphasize the form of language, but it draws students' attention to linguistic forms as they arise incidentally during lessons whose overriding focus is on meaning or communication.It was also stated by Unsal Sakiroglu(2020) who found that CF helps improve the language spoken by the learners and leads to a good teacher-student interaction which was veryimportant in language learning. Therefore, the teachers should consider to use face to face $\mathrm{CF}$ since it was easy to remember and understand the materialscomprehensively and it can enhance their learning accuracies.

\section{Learning Experiences}

The participants were assigned to express their learning experiences when the teachers used face to face $\mathrm{CF}$ or online $\mathrm{CF}$. The overall mean value of the participants was $=4,02$. It can be concluded that the students favored when their teachers used face to face $\mathrm{CF}$ than online $\mathrm{CF}$ habitually. They believed that the teachers should frequently use face to face $\mathrm{CF}$ than online $\mathrm{CF}$ as shown in the table 4.

The students agreed that the face to face $\mathrm{CF}$ ca facilitate them to give more experiences. As mentioned by Thi \& Thao (2017), they highlighted that the contribution of CF helps learners have more chances to revise their mistakes in class immediately after they have received face to face $\mathrm{CF}$ on their texts and it is a useful technique for the learners to become more independent, more responsible, and more motivated for their linguistic quality. Moreover, Zarifi (2017) who conducted a research showed that the participants preferred face to face $\mathrm{CF}$ 
since they could get comments on some of their mistakes from their teachers. Thus, teachers should be able to use face to face CF since it can motivate and give more experiences in learning.

Table 1

The Criteria for the Interpretation of the Mean Value (Tavakoli, 2012)

\begin{tabular}{ccc}
\hline Mean Value & Level of Frequency & Level of Agreement \\
\hline $4.21-5.00$ & Always & Strongly Agree \\
$3.41-4.20$ & Often & Agree \\
$2.61-3.40$ & Sometimes & Neutral \\
$1.81-2.60$ & Seldom & Disagree \\
$0.00-1.80$ & Never & Strongly Disagree \\
\hline
\end{tabular}

Table 2

Frequency level of Learning Effectiveness

\begin{tabular}{clccl}
\hline Items & Statements of Learning Effectiveness & Mean & SD & Agreement \\
\hline 1 & Face to face CF is more effective online CF & 4,16 & 0,87 & Agree \\
2 & Face to face CF is more helpful than online CF & 4,56 & 0,58 & Strongly agree \\
3 & Face to face CF is better in giving comments than online CF & 4,06 & 0,84 & Agree \\
4 & Face to face CF is more confusing than online CF & 2,76 & 1,27 & Neutral \\
5 & Face to face CF is more understandable than online CF & 4,2 & 0,78 & Agree \\
\hline Overall mean results & Og, & - & - \\
\hline N: 50 & & & &
\end{tabular}

Table 3

Frequency level of Learning Accuracies

\begin{tabular}{|c|c|c|c|c|}
\hline Items & Statements of Learning Accuracies & Mean & SD & Agreement \\
\hline 1 & Face to face CF further improves my writing skills than online CF & 4,16 & 0,65 & Agree \\
\hline 2 & $\begin{array}{l}\text { Face to face } \mathrm{CF} \text { is more comprehensible to check grammar errors than online } \\
\mathrm{CF}\end{array}$ & 4,18 & 0,77 & Agree \\
\hline 3 & To correct linguistic errors, face to face $\mathrm{CF}$ is more supportive than online $\mathrm{CF}$ & 4,06 & 0,89 & Agree \\
\hline 4 & $\begin{array}{l}\text { When teachers use face to face } \mathrm{CF} \text {, my writing errors are reduced rather than } \\
\text { in online } \mathrm{CF}\end{array}$ & 4 & 0,76 & Agree \\
\hline 5 & The results from face to face $\mathrm{CF}$ is easier to be revised online $\mathrm{CF}$ & 4,22 & 0,74 & Strongly Agree \\
\hline \multicolumn{2}{|r|}{ Overall mean results } & 4,12 & - & - \\
\hline
\end{tabular}

$\mathrm{N}: 50$

Table 4

Frequency level of Learning Experiences

\begin{tabular}{cllll}
\hline Items & Statements of Learning Experiences & Mean & SD & Agreement \\
\hline 1 & Face to face CF has more beneficial for learning than online CF & 4,14 & 0,73 & Agree \\
2 & Face to face CF saves more time than online CF & 3,42 & 0,97 & Agree \\
3 & Face to face CF gives more experiences than online CF & 4,18 & 0,77 & Agree \\
4 & Using face to face CF motivates my learning than online CF & 4,1 & 0,81 & Neutral \\
5 & In group discussion, face to face CF is more helpful to be used than online CF & 4,28 & 0,64 & Strongly Agree \\
\hline Overall mean results & 4,02 & - & - \\
\hline
\end{tabular}

$\mathrm{N}: 50$

After analyzing the students' interview transcripts, the following categorizations were obtained.

\section{What are the ESP students' beliefs towards their corrective feedback preferences?}

In order to understand what the students believed towards their corrective feedback preferences, the Focus Group Discussion (FGD) was applied. After analyzing the students' transcripts, the following thoughts and categorizations were obtained. Details in actual words were shown in the following table.

\section{Guided Corrective Feedback}

The data from FGD,as shown in table 5 indicated that the students believed that face to face interaction between teachers and students because they believed that teachers can explain what they had to do clearly and the students can get much information, listen and look at to the lecturers directly.

It was also underpinned by Jacobs \& Farrell (2003), Richards (2006), they stated that communicative language teaching became dominant and effective in language teaching process and interaction between teachers and learners in language classrooms has gained more importance.Moreover, the types of feedback between teacher and students were able to encourage students to solve problems and guide their own writing (Ferris, 2004; Bitchener \& Knoch, 2010; Bitchener \& Ferris, 2012). Importantly, it is to say that the corrective feedback provision, particularly face to face $\mathrm{CF}$, has brought positive impacts to guide the students. 
Although some teachers had conducted online CF, the students were still not sufficiently satisfied since they were more aware if the teachers used face to face CF. Providing feedback is an extremely valuable tool for indicating whether students are going in the right direction with their work or not (Williams \& Jasmine, 2003). In other words, the guided CF can reinforce students' understanding and correct them through the use of face to face $\mathrm{CF}$.

\section{Communicative Corrective Feedback}

The comments from FGD as shown in the table 6 indicated that the use of communicative face to face $\mathrm{CF}$ was more comfortable to improve students' accuracies. They agreed that by face to face $\mathrm{CF}$, they can know whether we have understood or not, and also realize our mistakes, easy to remember and understand the materials comprehensively. Additionally, the students believed that teachers can explain repeatedly until we understand and we can practice directly

The students' statements in face to face CF were line with Ellis (2009) who believed that a communicative approach in CF can contribute to language learning by fostering learner motivation and ensuring linguistic accuracy. In addition, in the middle of theirconversations and during teacher-student interactions, participants preferred to receive explicit and immediatecorrections (Lee, 2013).Importantly, the use of interpersonal cooperation strategies were deliverysystems for knowledge to students and asmeans for them to demonstrate that feedback was able to assist everystudent in coordination of collaborative learning process (Ferdian, 2019). It can be seen that teachers might have different ways to give $\mathrm{CF}$ butthey should know that the focus of CF was as important and long-term impacts on language development. Thus, in order to create positive and preferred feedback in class interaction, communication and negotiation can only occur if the teachers met and talked with the students directly.

\section{Encouraged Corrective Feedback}

The students' statements from table 7 showed that they favored face to face because their teachers could encourage them to learn. Importantly, they ways the teachers encouraged students could motivate and make them happy to learn where they could not find it in online.The students preferred face to face $\mathrm{CF}$ than online $\mathrm{CF}$ because their teachers could encourage and motivate them to learn.

What they stated was also in line with Ferris (2003) that the right, positive, and effective written feedback will encourage the learner to continue developing their skills. In addition, Ellis (2009) added that the preferred CF can be seen as a tool for strengthening student motivation and providing linguistic accuracy. Similarly,Diab (2015) and Mohammad and Rahman (2016) suggested that students' mistakes should bediscussed orally so that the students can become more aware.Thus, it showed that teachers' encouragements were able to helps students improve their English abilities and skills, as well as motivate them to take charge of their own learning.

Table 5

Students' comments from FGD for Guided Corrective Feedback Data Extract

\begin{tabular}{|c|c|}
\hline Data Extract & Themes \\
\hline $\begin{array}{l}\text { "We think that face to face or online has strengths. Both are good as long as the teachers } \\
\text { the teachers should be able to explain clearly and kindly but most importantly, we see this } \\
\text { in face to face" } \\
\text { "In face to face, we can get much information but it is not easy to understand our mistakes } \\
\text { in online and it is impossible to ask the teachers directly as soon as possible" } \\
\text { "We will listen and look at to the lecturers when they meet us but in online, we may only } \\
\text { see the text, comments, without seeing our teachers'expression" }\end{array}$ & $\begin{array}{l}\text { Guided Corrective } \\
\text { Feedback }\end{array}$ \\
\hline $\begin{array}{c}\text { Table } 6 \\
\text { Students' comments from FGD for Communicative Corrective Fee }\end{array}$ & \\
\hline
\end{tabular}

"With face to face, teachers can know whether we have understood or not and how far their understanding to the topics but in online it's difficult"

"By using face to face corrective feedback, we can realize our mistakes, easy to remember and understand the materials comprehensively but for online, it's quite difficult"

"Face to face allows us to ask the topics we do not understand and teachers can explain repeatedly until we understand and we can practice directly, to make Q\&A section, discussion, sometimes argue with teachers and of course it is not available in online"

Communicative Corrective Feedback

"I believe that face to face that students will not repeat their mistakes anymore because they get feedbacks directly and know their mistakes. We see that in online there are some risks such as network problem, low battery, low smartphone specifications, and no signal" 
Table 7

Students' comments from FGD for Encouraged Corrective Feedback Data Extract Themes

"We see that in face to face our teachers can enhance our learning process us and we feel
happy to study if the teachers can do that"
"Face to face is important for us because we can understand and absorb the topics easily
while in online, we have to read carefully sometimes difficult to find our mistakes"
"Face to face is more impressive than online corrective because we can see the face and Couraged Corrective
also the gesture of our teachers and it is different from what we learn through online"
"Face to face can stimulate students to discuss the materials while in online it only
focusses on assignments without any chitchats"

\section{Conclusion}

This study attempted to examine ESP students' preferences in learning English; face to face vs online corrective feedback. The results revealed that the students' preferences indicated that they favored their teachers used face to face corrective feedback frequently in learning English than online corrective feedbackbecause it can create the learning effectiveness, learning accuracies, and learning experiences. In addition, the students also believed that when the teachers implemented face to face $\mathrm{CF}$, they should be able to guide their learning, use communicative ways, and encourage them by using their learning preferences.

Additionally, taking these preferences into consideration could help students to increase their confidence, create a stronger teacher-student bond, and augment the speed of acquisition of language skills. Therefore, in order to achieve learning expectations and goals, teachers should be aware of the students' preferences for corrective feedback and include these in their teaching class.

\section{Acknowledged}

We would like to thank all of the students from Informatics Management department who have been very kind to us by being our research participants in this paper.

\section{References}

Al-Kathiri, F. (2015). Beyond the classroom walls: Edmodo in Saudi secondary school EFL instruction, attitudes and challenges. English Language Teaching, 8(1), 189-204.

Al-Okaily, R. (2013). Mobile learning and BYOD: Implementations in an intensive English program. Learning and Teaching in Higher Education: Gulf Perspectives, 10(2).

Al-Shehri, S. (2011). Proceedings from context in our pockets: Mobile phones and social networking as tools of contextualizing language learning. Paper presented at 10th World Conference on Mobile and Contextual Learning. Beijing, China.

Arslan, R.S. (2014). Integrating feedback into prospective English language teachers' writing process via blogs and portfolio. The Turkish
Online Journal of Educational Technology 13:1, 131-150.

Beare, P.L. (1989). The comparative effectiveness of videotape, audiotape and telecture. The American Journal of Distance Education 3, 5766.

Bitchener, J., Young, S., \& Cameron, D. (2005). The effect of different types of corrective feedback on ESL student writing. Journal of Second Language Writing 14, 191-205.

Chaudron, C. (1988). Second Language Classrooms: Research on Teaching and Learning. Cambridge, UK: Cambridge University Press

Chong, I. (2016). How students' ability levels influence the relevance and accuracy of their feedback to peers: A case study. Assessing Writing 31, 1-11. doi.org/10.1016/j.asw.2016.07.002

Chen Hsieh, J. S., Wu, W. C. V. \& Marek, M. W. (2017). Using the flipped classroom to enhance EFL learning. Computer Assisted Language Learning, 30(1/2), 1-21.

Chu, R. (2011). Effects of teachers' corrective feedback on accuracy in the oral English of English- majors college students. Theory and Practice in Language Studies, 1(5), 454-459.

Corder, S. (1974). 'Idiosyncratic Dialects and Error Analysis'. In J. Richard (Ed.), Error Analysis: Perspectives on second Language Acquisition (pp. 158-171). Essex: Longman.

Diab, N. M. (2015). Effectiveness of written corrective feedback: Does type of error and type of correction matter? Assessing Writing, 24, 1634.https://doi.org/10.1016/j.asw.2015.02.001Get rights and content

Dörnyei, Z. (2002). Questionnaires in second language research: Construction, administration, and processing. United States: Lawrence Erlbaum Associates.

Ellis R. (2009). Corrective feedback and teacher development. L2 Journal, (1), 3-18.

Ellis, R. (2010). A framework for investigating oral and written corrective feedback. Studies in Second Language Acquisition, 32, 335e349

Ferdian, N. R. (2019) Learning Strategies in Making Video Project Assignments in ESP Class. Linguists: Journal of Linguistics and Language Teaching, 5(1), 18-28. 
Ferris, D. (1995). Students reactions to teacher response in multiple-draft composition classrooms. TESOL Quarterly, 29(1), 33-53.

Ferris, D. R. (2003). Response to student writing: Implications for second language students. Mahwah, NJ: Lawrence Erlbaum Associates.

Ferris, D. (2014). Responding to student writing: Teachers' philosophies and practices. Assessing Writing, 19, 6-23.

Hedgcock, J., \& Lefkowitz (1994). Feedback on feedback: Assessing learner receptivity to teacher response in L2 composing. Journal of Second Language Writing, 3(2), 141-163.

Hyland, K. \& Hyland, F. (2006). Feedback on second language students' writing. Language Teaching, 39, 83-101. http://dx.doi.org/10.1017/S0261444806003399

Jacobs, G. M. \& Farrell, S. C. (2003). Understanding and implementing the CLT Paradigm. RELC Journal, 34(1), 5-30

Jin, C., \& Lin, J. (2016). Corrective Feedback in SLA: Theoretical Relevance and Empirical Research Corrective Feedback in SLA: Theoretical Relevance and Empirical, https://doi.org/10.5539/elt.v9n11p85

Kirovska-Simjanoska, D. (2016). Do ESP Students Prefer Face-To-Face Instruction Over Digitally Embedded Instruction? Blogs vs Reports Debates vs Online Discussion. Procedia - Social and Behavioral Sciences, 232(April), 170-176. https://doi.org/10.1016/j.sbspro.2016.10.042

Lee, E. J. (2013). Corrective feedback preferences and learner repair among advanced ESL students. System, 41(2).

Lee, I. (2004). Error correction in L2 secondary writing classrooms: The case of Hong Kong. Journal of Second Language Writing, 13(4), 285-312.

Mahfoodh, O. H. A. (2016). "I feel disappointed": EFL university students' emotional responses towards teacher written feedback. Assessing Writing 31, 1-20.

McCleary, I. \& Egan, M. (1989). Program design and evaluation: Two-way interactive television. The American Journal of Distance Education, 3, 5060.

Mohammad, T. F. \& Rahman, T. A. (2016). English learners perception on lecturers' corrective feedback. Journal of Arts and Humanities, 5(4), $10-21$.

Montgomery, J.L., \& Baker, W. (2007). Teacherwritten feedback: Student perceptions, teacher self-assessment, and actual teacher performance. Journal of Second Language Writing 16, 82-89.

Nelson, M. M., \& Schunn, C. D. (2009). The nature of feedback: How different types of peer feedback affect writing performance. Instructional Science, 37, 375-401. doi:10.1007/s11251-008-9053-x.
Rahimi, M., \& Zhang, L. J. (2015). Exploring nonnative English-speaking teachers' cognitions about corrective feedback in teaching English oral communication. System, 55, 111-122. https://doi.org/10.1016/j.system.2015.09.006

Richards, J. C. (2006). Communicative language teaching today. New York: Cambridge University Press.

Sangeetha, S. (2016). Edmodo and Padlet as a collaborative online tool in enriching writing skills in language learning and teaching. Global English-Oriented Research Journal, 1(4), 178184.

Sipayung, K. T. (2019). Developing Teaching Materials on English for Specific Purpose on Tourism Program of HKBP Grade Eleven 1Kammer. Asian EFL Journal, 23(6.3), 111-130.

Sonner, B. (1999). Success in the capstone business course-assessing the effectiveness of distance learning. Journal of education for Business, 7, 243-248.

Tavakoli, H. (2012). A Dictionary of Research Methodology and Statistics in Applied Linguistics. United States: Rahnama.

Thi, N., \&Thao, T. (2017). European Journal of English Language Teaching Teachers, Corrective Feedback on English Students , Writing, $177-197$ https://doi.org/10.5281/zenodo.437760

Unsal Sakiroglu, H. (2020). Oral corrective feedback preferences of university students in English communication classes. International Journal of Research in Education and Science. (IJRES), 6(1), 172-178

Wang, W. (2014). Students' perceptions of rubricreferenced peer feedback on EFL writing: A longitudinal inquiry. Assessing Writing, 19, 8096.

Williams, J., \& Jasmine, G. (2003). Providing feedback on ESL students' written assignments. TESL-EJ, 10(4), 1-6.

Zhang, Z. (2017). Student engagement with computergenerated feedback: A case study. ELT Journal, 71, 317e 328 .

Zhang, Z., \& Hyland, K. (2018). Student engagement with teacher and automated feedback on L2 writing. Assessing Writing, 36, 90e102.

Zheng, Y., \& Yu, S. (2018). Student engagement with teacher written corrective feedback in EFL writing: A case study of Chinese lowerproficiency students.Assessing Writing, 37, $13 \mathrm{e} 24$. 